\title{
Association of Calpastatin (CAST) Gene with Growth Traits and Carcass Characteristics in Bali Cattle
}

\author{
R. Putri, R. Priyanto, A. Gunawan, \& Jakaria* \\ Department of Animal Production and Technology, Faculty of Animal Science, Bogor Agricultural University \\ Jalan Agatis, Kampus IPB Darmaga Bogor 16680, Indonesia \\ (Received 20-04-2015; Reviewed 04-06-2015; Accepted 08-10-2015)
}

\begin{abstract}
Calpastatin (CAST) gene is well known as an inhibitor of muscle protein degradation and relates to muscle growth and meat tenderness. The objective of this study was to determine the association of CAST gene with growth traits and carcass characteristics in Bali cattle. A number of data from 35 Bali bulls were collected from BPTU Bali Cattle to obtain growth traits, carcass characteristics, and blood samples. Polymorphism of CAST gene in Bali bulls was analyzed by using PCR-RFLP and DNA sequencing. The association of CAST gene with growth traits and carcass characteristics were analyzed by using General Linear Model (GLM). The result showed that there were two genotypes (GG and AG) of CAST gene with allele frequencies of 0.857 and 0.143 , respectively, for G and A. Notably, mutation A to G occurred in 253 bp CAST fragment gene in Bali Cattle. Genotypes GG and AG of CAST gene significantly affected $(\mathrm{P}<0.05)$ the back-fat thickness and longissimus dorsi without a significant effect on the growth traits. It could be concluded that CAST gene had a potency as a marker gene for carcass quality in Bali cattle.
\end{abstract}

Key words: Bali cattle, CAST gene, PCR-RFLP, polymorphism

ABSTRAK

Gen kalpastatin (CAST) dikenal sebagai penghambat degradasi protein otot yang berkaitan dengan pertumbuhan otot dan keempukan daging. Tujuan penelitian ini adalah untuk mempelajari asosiasi gen kalpastatin dengan sifat pertumbuhan dan karakteristik karkas pada sapi Bali. Sebanyak 35 ekor sapi Bali pejantan dikoleksi dari BPTU Sapi Bali di Provinsi Bali untuk mendapatkan data sifat pertumbuhan, karakteristik karkas, dan sampel darah. Keragaman gen CAST pada sapi Bali dianalisis menggunakan teknik PCR-RFLP dan DNA sekuensing. Asosiasi gen CAST dengan sifat pertumbuhan dan karakteristik karkas dianalisis dengan menggunakan General Linear Model (GLM). Hasil penelitian menunjukkan bahwa genotipe yang didapatkan dari hasil penelitian ini adalah genotipe GG dan AG dengan frekuensi alel G dan A masing-masing adalah 0,857 dan 0,143. Terdapat perubahan basa adenin (A) menjadi guanin (G) pada posisi pb 253 fragmen gen CAST pada sapi Bali. Genotipe GG dan AG gen CAST berpengaruh nyata $(P<0,05)$ terhadap tebal lemak punggung dan longissimus dorsi, sedangkan sifat pertumbuhan tidak berbeda. Hal ini dapat disimpulkan bahwa gen CAST memiliki potensi sebagai penanda untuk karakteristik karkas pada sapi Bali.

Kata kunci: sapi Bali, gen CAST, PCR-RFLP, polimorfisme

\section{INTRODUCTION}

Selection in animal breeding is known as one of the breeding methods that can be used to increase the genetic quality of animals (Bourdon, 2000). Molecular technology can be used as a selection method to increase genetic quality based on marker-assisted selection

*Corresponding author:

E-mail: jakaria karman@yahoo.co.id
(MAS). Genetic marker that can be used in molecular study based on DNA is Polymorphism Chain ReactionRestriction Fragment Length Polymorphism (PCRRFLP). PCR-RFLP is one of genetic markers that use restriction enzyme in gene-polymorphism determination, especially in animal (Xiao et al., 2006).

One of Indonesia native cattle which have been recognized by FAO is Bali cattle (Bos javanicus) as the result of bull domestication (DGLS, 2003). Bali cattle has advantage that it is well adapted to tropical environmental stress and has a high fertility, especially when it 
is managed and fed with low quality diet (Purwantara et al., 2012). Therefore, Bali cattle are potential to be developed as beef cattle due to its good meat quality and low fat percentage (Bugiwati, 2007). Improvement of genetic quality of Bali cattle can be done on the economicallyvaluable traits such as growth traits and carcass characteristics. Growth traits and carcass characteristics have a high heritability (Baiduri et al., 2012; Kaswati et al., 2013; Putra et al., 2014), thus selection can be performed based on genotypes. The growth traits and carcass characteristics are controlled by many genes (Dunner et al., 2013). One of the genes that play a role in growth traits and carcass characteristics is calpastatin (CAST) gene (Schenkel et al., 2006).

Calpastatin (CAST) works by inhibiting protease enzyme to degrade muscle protein and relates to meat production, meat tenderness, and meat quality (Azari et al., 2012; Giusti et al., 2013). Calpastatin affects many processes, such as fusion regulation and myoblast migration, protein turn over, and muscle growth (Kempt et al., 2010; Schenkel et al., 2006). Muscle protein that plays an important role in growth of skeletal muscle is myofibril protein. Degradation occurred in myofibril proteins affects variation in loin-eye area (Longisimuss dorsi) (Kempt et al., 2010).

Several studies reported that CAST gene had an association with carcass and meat-quality characteristics such as Longissimus muscle area, marbling grade, fat, lean, fat grade, carcass weight, back-fat thickness, water content, cooking loss, $\mathrm{pH}$, meat tenderness, and water holding capacity (Davis et al., 2008; Casas et al., 2006; Curi et al., 2009; Schenkel et al., 2006; Li et al., 2010; Kubiak et al., 2004). Most of the studies on CAST gene were carried out in Bos taurus and Bos indicus cattle. The objective of this study was to find out the association of CAST gene with growth and carcass traits in Bali cattle (Bos javanicus).

\section{MATERIALS AND METHODS}

\section{Animal and Sampling}

A total number of 35 Bali bulls (3, 4, and 6 years of ages) were collected to obtain data on growth traits (birth weight, finish weight, average daily gain, chest circumference, body length, and shoulder height), carcass characteristics (the thickness of back fat and longissimus dorsi), and blood samples. Bali bulls in this study were collected from BPTU Bali Cattle, Pulukan, Jembrana, Bali Province. Growth traits (birth weight, finish weight, average daily gain, chest circumference, body length, and shoulder height) were measured based on SNI (2008).

The measurements of thickness of back fat and longissimus dorsi were carried out on the $12^{\text {th }}$ ribs, two third from medial to lateral side, by using Veterinary Ultrasound Scanner WED-3000V models (Gupta et al., 2013; Melendez \& Marchello, 2014). The image results were analyzed by using Image-J NIH software (ImageJ®, NIH, USA).

\section{SNP Identification and Genotyping}

The blood was extracted by standard
method from Green \& Sambrook Calpastatin gene (exon 1C and 1D), forward: 5' TGGGGCCCAATGAC GCCATCGATG 3' and reverse: 5' GGTGGAGCAGCACTTCTGATCACC 3', were designed by Palmer et al. (1998). Polymerase-chain reaction was performed by using PCR-mix in total volume of $50 \mu \mathrm{L}$ which consisted of $2 \mu \mathrm{L}$ genomic DNA, $0.8 \mu \mathrm{L}$ primer, $25 \mu \mathrm{L}$ Go Taq master mix, and $22.2 \mu \mathrm{L}$ distillation water. The PCR reaction was carried out with an initial pre-denaturation temperature of $95^{\circ} \mathrm{C}(5$ $\mathrm{min})$, followed by 35 cycles of denaturation at $95^{\circ} \mathrm{C}(10$ $\mathrm{s})$, annealing at $62^{\circ} \mathrm{C}(20 \mathrm{~s})$, and extension at $72^{\circ} \mathrm{C}(30 \mathrm{~s})$. The final extension was at $72^{\circ} \mathrm{C}(5 \mathrm{~min})$. The amplified PCR product was separated in $1.5 \%$ agarose gel containing ethidium bromide and then visualized by UV trans-illuminator.

The analysis of CAST gene polymorphism was conducted with PCR-RFLP (Polymorphism Chain ReactionRestriction Fragment Length Polymorphism) method. The amplicon was digested with AluI restriction enzyme which has 5'-AGCT-3' digestion site. The digestion reaction was carried out in $10 \mu \mathrm{L}$ of mixture which consisted of $0.3 \mu \mathrm{L}$ of AluI restriction enzyme, $5 \mu \mathrm{L}$ of PCR product, $0.7 \mu \mathrm{L}$ of buffer, and $1 \mu \mathrm{L}$ of distilled water. The reaction mixture was incubated at $37^{\circ} \mathrm{C}$ for $16 \mathrm{~h}$, after that the restriction fragment was separated in $2 \%$ agarose gel containing ethidium bromide and then visualized by UV trans-illuminator.

\section{Sequencing Analysis}

Sequencing was performed for individual Bali bull representing different genotypes. Forward and reverse primer fragments were sequenced by using sequencer machine (ABI Prims 3100-Avant Genetic Analyzer) in $1^{\text {st }}$ Base Selangor, Malaysia. The sequencing result was aligned by using MEGA version 4 software (Tamura et al., 2011).

\section{Statistical Analysis}

The genotypic (Xii) and allelic (Xi) frequencies from PCR-RFLP method were calculated according to Nei \& Kumar (2000).

$$
\mathrm{X}_{\mathrm{ii}}=\mathrm{n}_{\mathrm{ii}} / \mathrm{N} \quad \mathrm{X}_{\mathrm{i}}=\left(2 \mathrm{~N}_{\mathrm{ii}}+\Sigma \mathrm{n}_{\mathrm{ij}}\right) / 2 \mathrm{~N}
$$

where:

$\mathrm{n}_{\mathrm{ii}}=$ the number of individual of $i$ genotype

$\mathrm{n}_{\mathrm{ij}}=$ the number of individual of $i j$ genotype

$\mathrm{N}=$ the total of individual samples.

The association analysis between CAST gene and growth traits (finish weight, average daily gain, chest circumference, body length, and shoulder height) and carcass quality (back fat thickness and longissimus dorsi) were analyzed by using the following General Linear Model (GLM) by ANCOVA (Kaps \& Lamberson, 2004) with a mathematical model as follow:

$$
\mathrm{Y}_{\mathrm{ij}}=\mu+\alpha_{\mathrm{i}}+\beta \mathrm{X}_{\mathrm{ij}}+\mathrm{E}_{\mathrm{ij}}
$$


where:

$\mathrm{Y}_{\mathrm{ij}}=$ observed value

$\mu=$ overall mean

$\alpha_{\mathrm{i}}=$ effect for genotype (GG and AG)

$\beta=$ regression coefficient

$X_{i j}=$ covariant (age)

$\mathrm{E}_{\mathrm{ij}}=$ random error

\section{RESULTS AND DISCUSSION}

\section{Polymorphism of CAST Gene}

Calpastatin gene amplification in Bali bull was contained in annealing at the optimal temperature of $60^{\circ} \mathrm{C}(20 \mathrm{~s})$. The result of CAST amplification in Bali bull showed 624 base pairs (bp) PCR product (Figure 1). The amplification process of DNA fragment was determined by some factors, such as primer concentration, amplification temperature, denaturation duration, DNA samples, and $\mathrm{MgCl}_{2}$ concentration (Williams 2005).
The genotyping result of CAST gene in Bali bull showed two genotypes (GG and AG) (Figure 2). GG genotype was found in 10 samples and AG genotype was found in 25 samples. The homozygous of GG genotype (no restriction in $253 \mathrm{bp}$ position) produced one band of $474 \mathrm{bp}$, whereas the heterozygous of AG genotype produced three bands of $474 \mathrm{bp}, 336 \mathrm{bp}$, and 138 bp (Figure 3). Those genotypes were different from genotypes reported by previous study. Kubiak et al. (2004) showed that there were three genotypes (GG, GC, and $\mathrm{CC}$ ) in various breeds of cattle in the same fragment of CAST. The result showed there was an A (adenine) to $\mathrm{G}$ (guanine) mutation in $253 \mathrm{bp}$ of the restriction site of CAST $\mid A l u$ I (Figure 4). In this study, the genotype frequencies for GG and AG were 0.714 and 0.286 , respectively. The allele frequencies for $G$ and $A$ were 0.857 and 0.143 , respectively. This result showed that $G$ allele was higher frequency than A allele, because there was no AA genotype that was found in this population. AA genotype was not found because of the uncontrolled

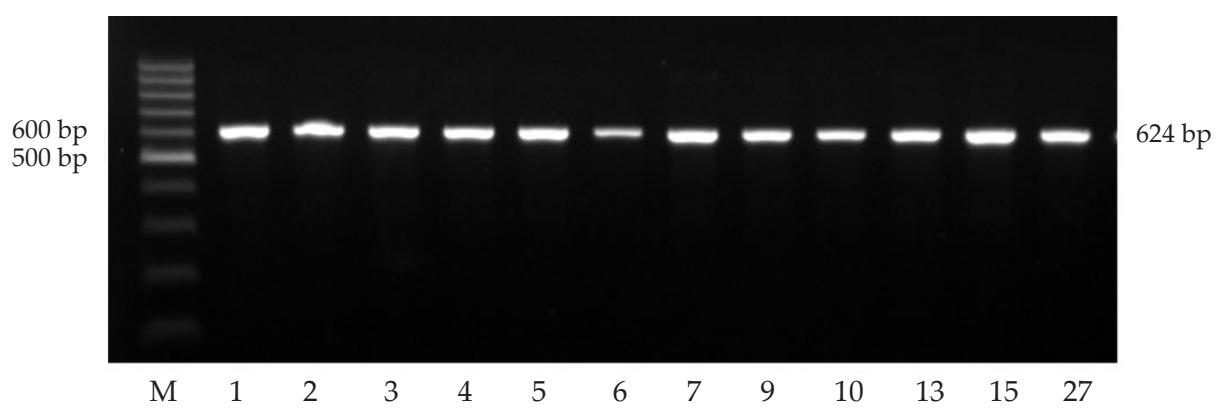

Figure 1. The result of CAST gene PCR fragments electrophoresis. Note: $\mathrm{M}=$ marker, 1-27 = number of animal)

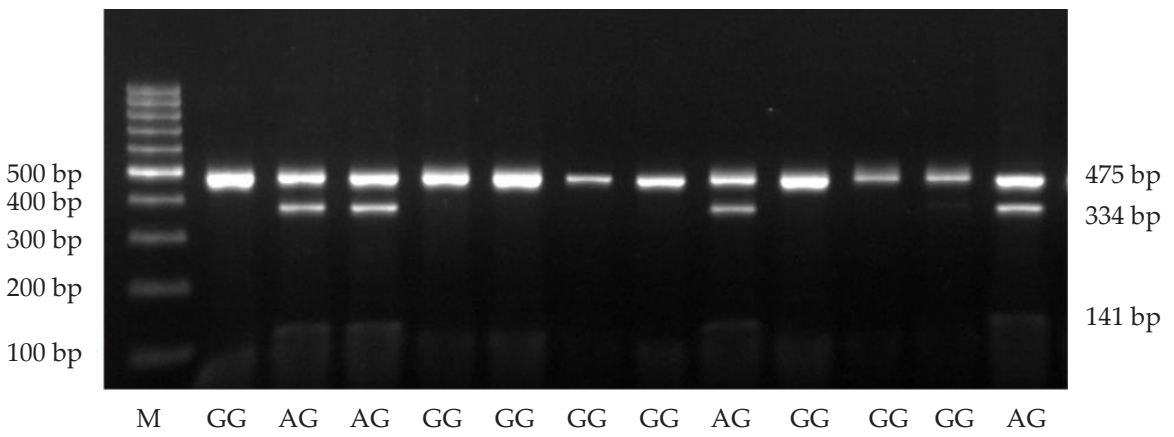

Figure 2. The result of $\mathrm{CAST} \mid \mathrm{AluI}$ fragment restriction on $2 \%$ agarose gel electrophoresis. Note: $\mathrm{M}=$ marker, GG, $\mathrm{AG}=$ genotype.

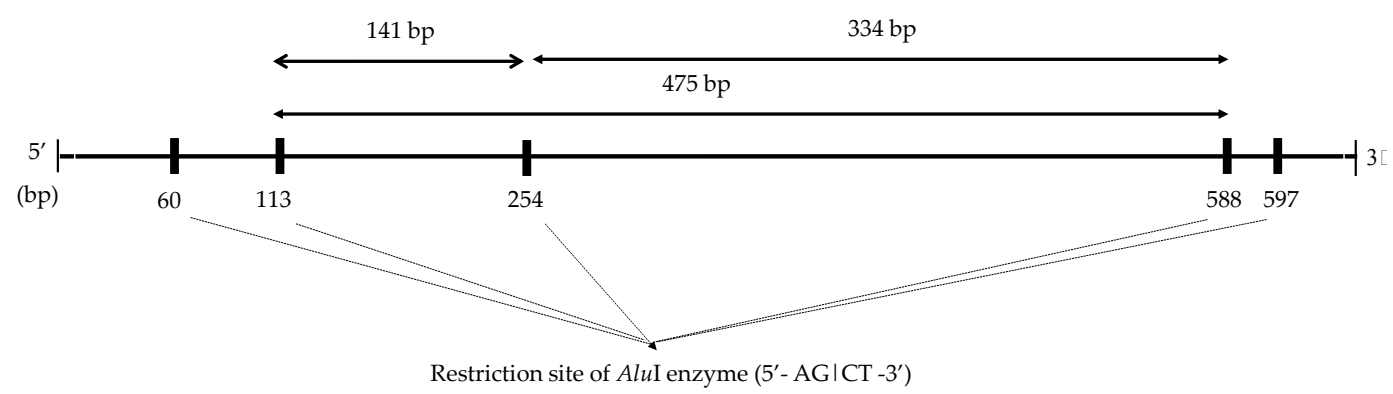

Figure 3. Restriction site of AluI enzyme in Bali bull 


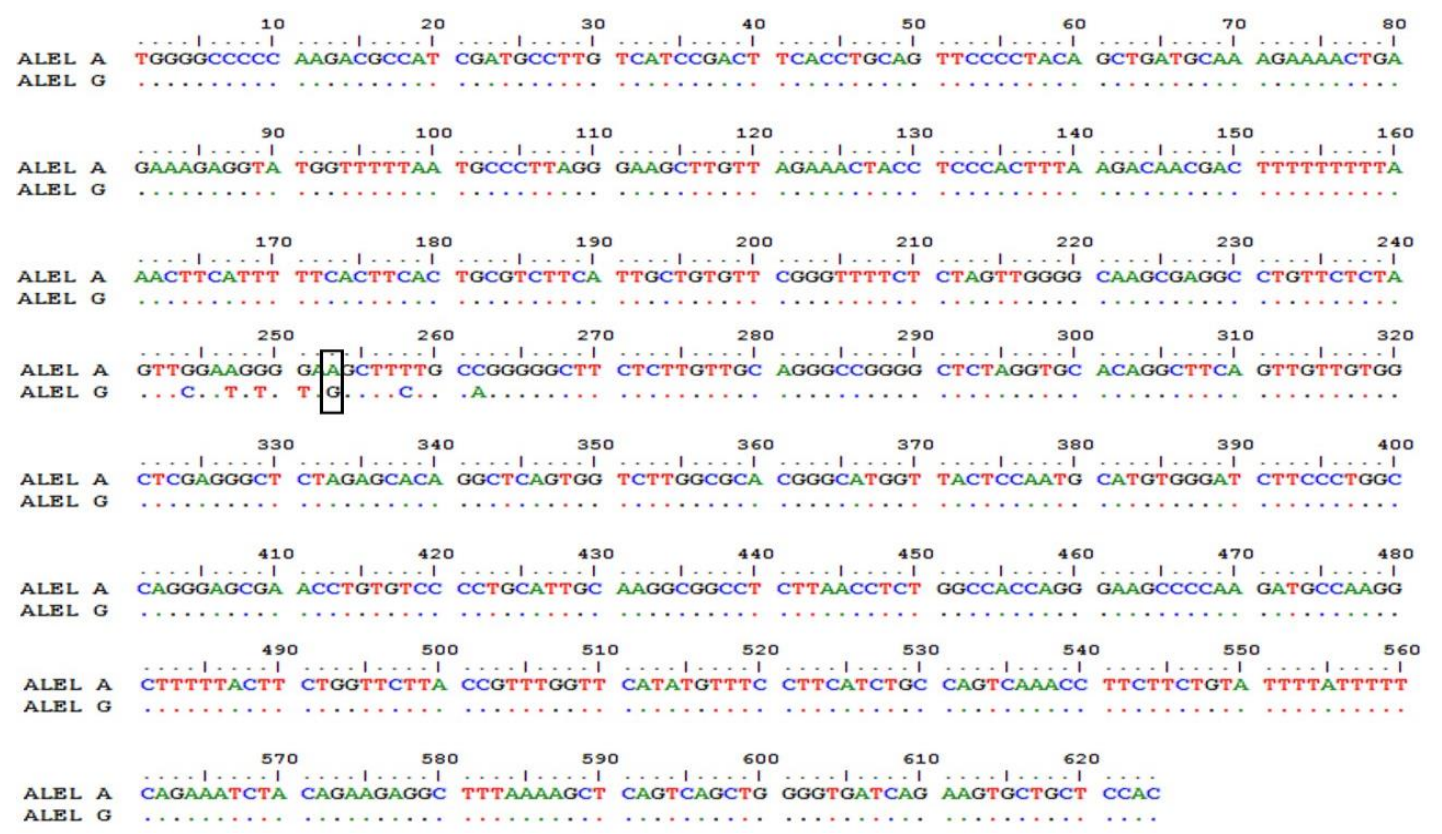

Figure 4. Mutation of A (adenine) to G (guanine) in $253 \mathrm{bp}$ of the restriction site of CAST $\mid$ AluI in Bali bull

selection that was occurred in this population. However, the diversity of CAST $\mid$ AluI in population of Bali bulls in this study was polymorphic that was represented by the allele frequencies that was lower than 0.99 or higher than 0.01 (Nei \& Kumar, 2000).

\section{Association Analysis}

This study revealed an association of CAST with carcass characteristics (thickness of back fat and longissimus dorsi) (Table 1). However, the association of CAST was not found with growth traits (Table 1).

Figure 5 showed the result of ultrasound measurement of the thickness of back fat and Longissimus dorsi. The GG genotype had significantly higher back-fat thickness than that of AG. In contrast, the AG genotype had significantly higher muscle thickness of longissimus

Table 1. The association of CAST gene with growth traits and carcass quality in Bali bulls

\begin{tabular}{lrr}
\hline \multirow{2}{*}{ Characteristic } & \multicolumn{2}{c}{ Genotype } \\
\cline { 2 - 3 } & \multicolumn{1}{c}{ GG $(\mathrm{n}=25)$} & \multicolumn{1}{c}{ AG $(\mathrm{n}=10)$} \\
\hline Birth weight $(\mathrm{kg})^{*}$ & $17.800 \pm 0.200$ & $17.480 \pm 0.276$ \\
Finish weight $(\mathrm{kg})$ & $402.075 \pm 8.866$ & $421.212 \pm 14.429$ \\
Shoulder height $(\mathrm{cm})$ & $127.164 \pm 0.985$ & $128.390 \pm 1.603$ \\
Chest circumference $(\mathrm{cm})$ & $181.807 \pm 1.568$ & $184.782 \pm 2.552$ \\
Body length $(\mathrm{cm})$ & $135.574 \pm 1.167$ & $139.766 \pm 1.900$ \\
Average daily gain $(\mathrm{kg} / \mathrm{d})$ & $0.265 \pm 0.007$ & $0.272 \pm 0.012$ \\
Thickness of back fat $(\mathrm{mm})$ & $2.324 \pm 0.097^{\mathrm{a}}$ & $1.935 \pm 0.157^{\mathrm{b}}$ \\
Thickness of Longissimus dorsi & $57.577 \pm 1.533^{\mathrm{a}}$ & $63.818 \pm 2.495^{\mathrm{b}}$ \\
(mm) & & \\
\hline
\end{tabular}

Note: Means in the same row with different superscripts differ significantly $(\mathrm{P}<0.05) ; \mathrm{n}=$ number of animal; ${ }^{*}=$ analyzed by ANOVA. dorsi. The back-fat thickness is a parameter indicating carcass fattiness and meat yield (Gupta et al., 2013).The ranges of back-fat thickness for AG and GG in this study were $1.935 \pm 0.157$ and $2.324 \pm 0.097 \mathrm{~mm}$, respectively. The result showed that thickness of back fat in Bali bulls can be classified as an ideal carcass for traditional market. Halomoan et al. (2001) showed that the range of back-fat thickness for traditional market was from 1 up to $5 \mathrm{~mm}$. There are several factors which influence the carcass composition, such as growth rate, nutrition, age, and body weight (Soeparno, 2005). The increase in back fat decreases meat proportion, or the decrease in back fat increases meat proportion (Irshad et al., 2013). The Bali bull with AG genotype showed a thinner back fat and tended to have a larger body frame. Therefore the Bali cattle with a larger body frame in this study might yield a higher proportion of meat.

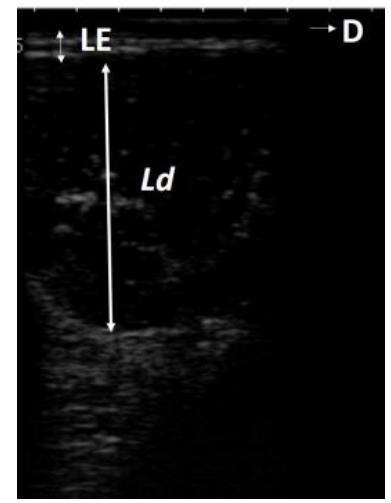

Figure 5. The result of ultrasound using Image-J NIH in Bali bull. Note: $\mathrm{Ld}=$ Longissimus dorsi, $\mathrm{Le}=$ back fat, $\mathrm{D}=$ dermis. 


\section{CONCLUSION}

The CAST gene polymorphisms (GG and AG genotypes) had significant effect on longissimus dorsi and back-fat thickness traits, but it did not affect the growth traits. The CAST gene was a potential marker for longissimus dorsi and back-fat thickness in Bali cattle.

\section{ACKNOWLEDGEMENT}

This work was financially supported by the Ministry of Agriculture, Republic of Indonesia under the program of KKP3N (Kerjasama Kemitraan Penelitian dan Pengembangan Pertanian Nasional) 2014 with the contract number 57/PL.220/I.1/3/2014.K. We thank Muhammad F. Ulum, DVM, MSc. for the assistance in ultrasound measurement.

\section{REFERENCES}

Azari, M. A., E. Dehnavi, S. Yousefi, \& Shahmohamadi. 2012. Polymorphism of calpastatin, calpain, and myostatin gene in native dalagh sheep in Iran. Slovak J. Anim. Sci. 45: 1-6.

Baiduri, A. A., Sumadi, \& N. Ngadiono. 2012. Pendugaan nilai heritabilitas, ukuran tubuh pada umur sapih dan umur setahun sapi bali di Balai Pembibitan Ternak Unggul Sapi Bali, Jembrana, Bali. Buletin Peternakan 36: 1-4.

Bourdon, R. M. 2000.Understanding Animal Breeding.PrenticeHallInc, New Jersey.

Bugiwati, S. R. A. 2007. Body dimension growth of calf bull in Bone and Barru District, South Sulawesi. J. Sains Tekno. 7: 103-108.

Casas, E., S. N. White, T. L. Wheeler, S. D. Shackelford, M. Koohmaraie, D. G. Riley, C. C. Chase, D. D. Jhonson, \& T. P. L. Smith. 2006. Effect of calpastatin and $\mu$-calpain markers in beef cattle on tenderness traits. J. Anim. Sci. 84: 520-525.

Curi, R. A., L. A. L. Chardulo, M. C. Mason, M. D. B. Arrigoni, A. C. Silvera, \& H. N. Ed Olivera. 2009. Effect of singlet nucleotide polymorphism of CAPN1 and CAST genes on meat traits in Nellore beef cattle (Bos indicus) and in their crosses with Bos taurus. Anim Genet. 40: 456-462. http:// dx.doi.org/10.1111/j.1365-2052.2009.01859.x

Davis, G. P., S. S. Moore, R. D. Drinkwater, W. R. Shorthose, I. D. Loxon, W. Barendes, \& D. J. Hetzel. 2008. QTL for meat tenderness in the $M$. Longissimus lumborum of cattle. Anim Genet. 39: 40-45. http://dx.doi.org/10.1111/j.13652052.2007.01677.x

Directorate Generale of Livestock Services (DGLS). 2003. National Report on Animal Genetic Resources Indonesia. Directorate Generale of Livestock Services, Directorate of Livestock Breeding. Indonesia.

Dunner, S., N. Sevane, D. Garcia, O. Cortes, A. Valentini, J. L. Williams, B. Mangin, J. Canon, \& H. Leveziel. 2013. Association of Gees involved in carcass and meat quality traits in 15 European bovine breeds. Livest. Sci. 154: 34-44. http://dx.doi.org/10.1016/j.livsci.2013.02.020

Giusti, J., E. Castan, M. D. Pai, M. D. B. Arrigoni, S. R. Baldin, \& H. N. D. Olivera. 2013. Expression of genes related to quality of Longisimuss dorsi muscle meat in Nellore (Bos indocus)and Canchim (5/8 Bos taurus x 3/8 Bos indicus) cattle. Meat Sci. 94: 247-252. http://dx.doi.org/10.1016/j.meat$\underline{\text { sci.2013.02.006 }}$

Green, \& J. Sambrook.1989. Molecular Cloning: A Laboratory Manual. CSH Laboratory Pr., USA.
Gupta, S., A. Kumar, S. Kumar, Z. F. Bhat, H. R. Hakeem, \& A. P. S. Abrol. 2013. Recent trends in carcass evaluation techniques: A review. J. Meat. Sci. 2: 50-55.

Halomoan, F., R. Priyanto, \& H. Nuraeni. 2001. Karakteristik ternak dan karkas sapi untuk kebutuhan pasar tradisional dan pasar khusus. Med. Pet. Edisi Khusus 24: 12-17.

Irshad, A., G. Kandeepan, S. Kumar, K. A. Ashish, M. R. Vishnuraj, \& V. Shukla. 2013. Factor influencing carcass composition of livestock: A Review. J. Anim. Prod. Adv. 3: $177-186$.

Kaps, M., \& W. R. Lamberson. 2004. Biostatistics for Animal Science. CABI Publishing, London. http://dx.doi. org $/ 10.1079 / 9780851998206.0000$

Kaswati, Sumadi, \& N. Ngadiono. 2013. Estimasi nilai heritabilitas berat lahir, sapi, dan umur satu tahun pada sapi bali di Balai Pembibitan Ternak Unggul Sapi Bali. Buletin Peternakan 37: 74-78.

Kempt, C. M., P. L. Sensky, R. G. Bardsley, P. J. Buttery, \& T. Parr. 2010. Tenderness - An enzymatic view. Meat Sci. 84: 248-256. http://dx.doi.org/10.1016/j.meatsci.2009.06.008

Kubiak, E. J., S. J. Rosochacki, K. Wicinska, T. Szreder, \& T. Sakowski. 2004. A novel RFLP/AluI polymorphism of the bovine calpastatin (CAST) gene and its association with selected traits of beef. Animal Science Papers and Reports 22: 195-204.

Li, J., Zhang, Q. F. Gan, J. Y. Li, H. J. Gao, Z. R. Yuan, X. Gao, J. B. Chen, \& S. Z. Xu. 2010. Association of CAST gene polimorphisms with carcass and meat quality traits in chinese commercial cattle herds. Asian-Aust J. Anim. Sci. 23: 1405-1411.

Melendez, L. J. \& J. A. Marchello. 2014. The efficacy of ultrasound to determine certain carcass traits in Grains-fed beef cattle. International Journal of Science Commerce and Humanities 2: 145-154.

Nei, M. \& S. Kumar. 2000. Molecular Evolution and Phylogenetics. Oxford Univ Pr., New York.

Palmer, B. R., N. Roberts, J. G. H. Hickford, \& R. Bickerstaffe. 1998. Rapid Communications: PCR-RFLP for MspI and NcoI in the ovine calpastatin gene. J. Anim. Sci. 76: 1499 -1500 .

Purwantara, B., R. R. Noor, G. Andersson, \& H. RodriguezMartinez. 2012. Banteng and Bali cattle in Indonesia: status and forecasts. Reprod. Domest. Anim. 47: 2-6. http:// dx.doi.org/10.1111/j.1439-0531.2011.01956.x

Putra, W. P. B., Sumadi, \& T. Hartatik. 2014. Korelasi genetik pada sifat pertumbuhan sapi Aceh di kecamatan Indrapuri, Provinsi Aceh. Jurnal Agripet 14: 37-41.

Schenkel, F. S., S. P. Miller, Z. Jiang, I. B. Mandell, X. Ye, H. Li, \& J. W. Wilton. 2006. Association of a single nucleotide polymorphism in the calpastatin gene with carcass and muat quality Straits of beef cattle. J. Anim. Sci. 84: 291-299.

SNI [Standar Nasional Indonesia]. 2008. Bibit Sapi Bali. SNI 7355: 2008. Badan Standardisasi Nasional, Jakarta.

Soeparno. 2005. Ilmu dan Teknologi Daging. Gajah Mada University Pr., Yogyakarta.

Tamura, K., D. Peterson, N. Peterson, G. Stecher, M. Nei, \& S. Kumar. 2011. MEGA5: Molecular evolutionary genetics analysis using maximum likelihood, evolutionary distance, and maximum parsimony methods. Mol. Biol. Evol. 28: 2731-2739. http://dx.doi.org/10.1093/molbev/msr121

Williams, J. L. 2005. The use of marker-assisted selection in animal breeding and biotechnology. Rev. Sci. Tech. Off. Int. Epiz. 24: 379-391.

Xiao, J., X. Xin, X. Luan, D. Wei, \& S. Yang. 2006. A modified simpel RFLP-PCR method for single nucleotide polymorphism (SNP) typing. Genet. Mol. Biol. 29: 562-565. http:// dx.doi.org/10.1590/S1415-47572006000300028 